\title{
Prof. Dr. Cevat ALKAN through the eyes of his students
}

\author{
Necmettin TEKER ${ }^{*}$ \\ Gülcan NUMANOĞLU**
}

\author{
Salih BARDAKCI ${ }^{* *}$ \\ Mehmet KURT ${ }^{* * *}$
}

\begin{abstract}
The aim of this study is to describe Prof. Dr. Cevat Alkan and his contributions to the development of the field of educational technology in Turkey, via his students' views. Prof. Dr. Alkan is the founder of the field of educational technology in Turkey. In 1975, he became an associate professor with the thesis entitled "Eğitim Teknolojisi (Educational Technology)", and in 1983 with the thesis entitled "Açık Üniversite (Open University)" owned the title of professor. Besides, until 1996 he performed as a head of educational technology department at Faculty of Educational Sciences in Ankara University. And during this period, he provided fundamental contributions for training dozens of students of undergraduate and graduate level in the field of educational technology both in Ankara University and other universities in Turkey. In this study, history method was used. In this process, an interview was carried out with Prof. Dr. Alkan's family about his daily and academic life. And an online qualitative questionnaire developed by the researchers was administered to Prof. Dr. Alkan's students determined by the purposive sampling method about his academic characteristics. Based on the data, firstly we described Prof. Alkan's short life story and academic activities. Afterwards, his academic characteristics which have an important place in today's educational technology field culture in Turkey were identified. As a conclusion, Prof. Dr. Alkan's professional qualifications are grouped under three themes: scientific, instructor and personality characteristics.
\end{abstract}

Keywords: Prof. Dr. Cevat ALKAN, educational technology, the history of educational technology field in Turkey.

\footnotetext{
${ }^{*}$ Assist. Prof. Dr., Ankara University, Faculty of Educational Sciences, Ankara,Turkey. E-mail: teker@ankara.edu.tr ${ }^{* * *}$ Res. Assist., Ankara University, Faculty of Educational Sciences, Ankara, Turkey. E-mail: sbardakci@ankara.edu.tr ${ }^{* * *}$ Specialist., Ankara University, Faculty of Educational Sciences, Ankara, Turkey. E-mail: numan@ankara.edu.tr Instructor Dr., Ankara University, Faculty of Educational Sciences, Ankara, Turkey. E-mail: kurt@ankara.edu.tr A part of this research was presented at the 5th International Computer \& Instructional Technologies Symposium which was organised in honor of Prof. Dr. Cevat ALKAN, 22-24 September 2011, Firat University Faculty of Education, Elzlğ-Turkey.
} 


\section{SUMMARY}

Purpose and significance: Prof. Dr. Ömer Cevat Alkan is the first scientist who carried out studies at the field of educational technology in Turkey. He has started to lecture at the field of educational technology since 1972 when he started to work at Faculty of Educational Sciences in Ankara University. Then, he set up the educational technology department and carried out for a long time its leadership. Besides his scientific findings and productions, he brought up most scientists; he was the initiator of expending, developing and setting educational technology in Turkey. This study aims to search out the life story of Prof. Dr. Alkan; and the origin of educational technology field in Turkey.

Methods: Research was designed based on historical research model. In the period of research, by making discussing of Prof. Dr. Cevat Alkan's family and his close relatives, it was aimed to describe his short life story. Besides, semi-structured qualitative questionnaire which is made by researchers, by basing on similar scientific researches and making use of expert opinion, is carried out to participant group, determined by the purposive sampling method, as online. Regarding these findings, themes which introduce Prof. Dr. Alkan with his different attitudes are defined. The text formed throughout these themes, was examined into his studentscolleagues who studied with him for a long time.

Results: Prof. Dr. Ömer Cevat Alkan was born at 22 December 1929 nearby Istanbul. His mother's name is Makbule, father's name is Ferhat. He had got three brothers and his father was a forest guard. In 1965, earning a scholarship, he completed the post graduate in Curriculum Development at The Stout State University (1965-1967) and between 1967-1970 he completed the doctorate at the Philosophy Education, Management in Higher Education, Teacher Training and Technical Education in The Ohio State University. In 1972, he started to work at the Faculty of Educational Sciences in Ankara University and the curriculum and instruction department. In 1975, he be came an associate professor with the thesis title of "Education Technology", in 1983, he became a professor with the thesis title of "Open University". Prof. Dr. Alkan has carried out thesis studies and, besides, lectured philosophy of education and vocational and technical education lessons, after the starting Faculty of Educational Sciences. In 1981, he left from the curriculum and instruction department under the title of technical education department. From this date, Prof. Dr. Alkan went on his lessons and scientific studies related with educational technology in the 
technical education department. In 1987, after the closing technical education department, Prof. Dr. Alkan founded the education technology department inside the curriculum and instruction department and when he went on the head of department until the 1996. In February 1996, he retired from the Faculty of Educational Sciences. Besides academic studies, between1978-1979, he carried out the duties of an Undersecretary of Technical and Vocational Education in Ministry of Education in Turkey. In 10 July 2007, he was died. Besides many students he trained, he left behind; 12 investigations, 21 books, 31 presentations and 40 articles; and total 104 writing studies and 5 books and 9 articles total 14 translations, and different speeches. Participants combine notes related with Prof. Dr. Alkan in this point: discipline of study, determination, punctuality, multifaceted and value different views, democracy.

Conclusions: Between the 1972-2007, Prof. Dr. Alkan, during the 35 years, he made an effort for expanding educational technology field as both science discipline and practice field in Turkey. Besides dense studies, most students grow up who follow him. In addition to this, he gave to students dense scientific information, line of vision and a common scientific culture. Some of the first he performed as follows:

- He was the person who set up the educational technology discipline first in Turkey.

- He wrote first Turkish book in this field.

- He grows up the first doctorate student at educational technology in Turkey.

- He organized the first conference related educational sciences in Turkey.

- He carried out the first editorship of journal in the distance education in Turkey.

Both these science power and regards with "father of the education technology field in Turkey" is named Prof. Dr. Alkan. We commemorate him with respect that he had started working in Ankara University, Faculty of Educational Sciences on the 40th years. 


\section{Öğrencilerinin Gözüyle Prof. Dr. Cevat ALKAN}

\author{
Necmettin TEKER ${ }^{*}$ \\ Gülcan NUMANOĞLU***
}

\author{
Salih BARDAKCI*** \\ Mehmet KURT
}

ÖZ. Bu çalışmanın amacı bir biliminsanı olarak Prof. Dr. Cevat Alkan'ı tanıtmak ve Türkiye'de eğitim teknolojisi alanının gelişimine sağladığı katkıları, öğrencilerinin izlenimlerinden hareketle ortaya koymaktır. Prof. Dr. Alkan lisans öğrenimini Ankara Teknik Öğretmen Okulu'nda, yüksek lisans öğrenimini Amerika Birleşik Devletleri'nde "Stout State" Üniversitesi'nde Eğitimde Program Geliştirme alanında, doktora öğrenimini ise "Ohio State" Üniversitesi'nde Eğitim Felsefesi, Yükseköğretimde Yönetim, Öğretmen Yetiştirme ve Teknik Eğitim alanlarında tamamlamıştır. 1972 y1lında Ankara Üniversitesi Eğitim Bilimleri Fakültesi’nde öğretim üyesi olarak ders vermeye başlamış; 1975 yılında "Eğitim Teknolojisi" adlı tezle üniversite doçenti ve 1983 yılında "Açık Üniversite" adlı tezle profesör ünvanını almıştır. Yine A. Ü. Eğitim Bilimleri Fakültesinde 1996 yılına kadar Eğitim Teknolojisi Anabilim Dalı Başkanlığg'nı yürütmüş ve bu dönemde gerek Ankara Üniversitesi gerekse diğer üniversitelerde devam eden programlarda eğitim teknolojisi alanında lisans ve lisansüstü düzeyde onlarca öğrenci yetiştirmiştir. Araştırmada Prof. Dr. Alkan’ın ailesi ve yakınlarıyla görüşmeler gerçekleştirilmiş, yanı sıra araştırmacılar tarafından geliştirilen nitel bir anket formu, amaçlı örnekleme yöntemi ile belirlenen katılımcı gruba çevrimiçi olarak uygulanmıştır. Elde edilen veriler üzerinden Prof. Dr. Alkan'1 çeşitli yönleriyle tanıtan temalar belirlenmiştir. Böylece ülkemizde eğitim teknolojisi alanının kurucusu Prof. Dr. Alkan'ın kısa yaşam öyküsü, bilimsel kişiliği ve katkıları, yakın çevresi ve yetiştirdiği bilim insanlarının izlenimleri aracılığıyla betimlenmeye çalışılmıştır.

Anahtar Sözcükler: Prof. Dr. Cevat Alkan, Eğitim teknolojisi, Türkiye'de eğitim teknolojisi alanının tarihi.

\footnotetext{
${ }^{*}$ Yrd. Doç. Dr., Ankara Üniversitesi, Eğitim Bilimleri Fakültesi, Ankara, Türkiye. E-posta: teker@ankara.edu.tr *** Arș. Gör., Ankara Üniversitesi, Eğitim Bilimleri Fakültesi, Ankara, Türkiye. E-posta: sbardakci@ankara.edu.tr ${ }^{* * * *}$ Uzman., Ankara Üniversitesi Eğitim Bilimleri Fakültesi, Ankara, Türkiye. E-posta: numan@ankara.edu.tr **** Öğrt. Gör. Dr., Ankara Üniversitesi Eğitim Bilimleri Fakültesi, Ankara, Türkiye. E-posta: kurt@ankara.edu.tr Bu araştırmanın bir bölümü 22-24 Eylül 2011 tarihleri arasında Fırat Üniversitesi Eğitim Fakültesi’nde Prof. Dr. Cevat ALKAN adına gerçekleştirilen 5. Uluslararası Bilgisayar ve Öğretim Teknolojileri Sempozyumu'nda sözlü bildiri olarak sunulmuştur.
} 


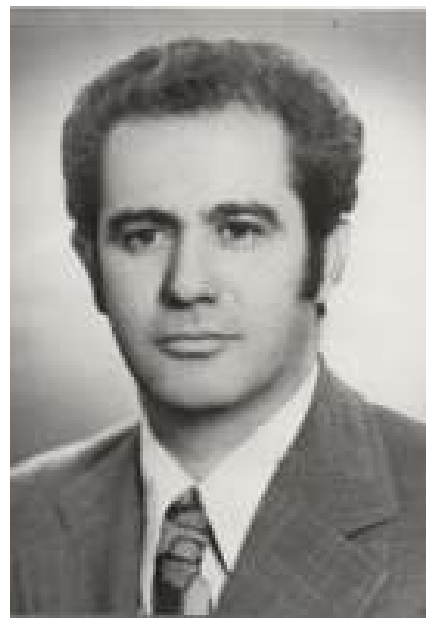

“...Bugün artık eğitim endüstrisi ve eğitim teknolojisi bir olgudur. Televizyon, programlı öğretim, ögretme makinalarl, komputerli öğretim, bilgi işlem sistemleri gibi uygulamalar sonucu olarak okulların endüstrileşmesi; tesis, organizasyon, öğrenme-öğretme stratejileri ve öğretmen-öğrenci fonksiyonlart açısından alışılmış eğitim kalıplarının değişmesi ve nihayet sistemler yaklaşımı, bireysel kabiliyetlerin çeşitliliği, yaratıcılık, keşfetme ve problem çözme kavramlarının önem kazanması şeklinde beliren öğretme-ögrenme süreçlerindeki yenilikler bu oluşumu simgeleyen tipik gelişmelerdir. Böyle bir gelişim ve oluşum içerisinde bulunan eğitimde yeni teknolojilerden söz etmek kadar doğal bir şey olamaz."

Alkan, 1974: 339 


\section{GİRIŞ}

Prof. Dr. Ömer Cevat Alkan Türkiye'de eğitim teknolojisi alanında çalışmalar yürüten ilk biliminsanıdır. O dönemki adıyla Ankara Üniversitesi Eğitim Fakültesi'nde göreve başladığı 1972 tarihinden itibaren eğitim teknolojisi alanında dersler vermeye başlamış, sonrasında Eğitim Teknolojisi Anabilim Dalı'nı kurmuş ve uzun bir dönem başkanlığını yürütmüştür. Bilimsel çalışmaları ve ürünlerinin yanı sıra pek çok biliminsanı da yetiştirmiş; eğitim teknolojisi alanının ülkemizde kurulması, gelişmesi ve yayılmasında öncü olmuştur. Bu çalışma Prof. Dr. Alkan'ın kısa yaşam öyküsü ve bilimsel özellikleriyle birlikte, Türkiye'de eğitim teknolojisi alanının doğuşu ve gelişimine temel olan bilimsel kültüre ilişkin bilgileri de ortaya çıkarmayı amaçlamaktadır. Reiser ve Dempsey’e (2005) göre eğitim teknolojisi alanında çalışan bir uzman sadece tasarım sürecine dönük yetilerle donanmış kimse değildir. Alanın geçmişini, gelişimini ve mevcut durumunu bilen; böylelikle alanın doğasına ilişkin hassasiyet geliştirerek oluşacak yeni değişim ve eğilimleri kestirebilen kimsedir. $\mathrm{Bu}$ düşünceden hareketle, araştırmanın ülkemiz eğitim teknolojisi camiasına alanın Türkiye'deki geçmişi ve gelişimine ilişkin bilgiler sunabileceği düşünülmektedir.

\section{YÖNTEM}

Araştırma tarih araştırması modelinde kurgulanmıştır. Alanyazın incelendiğinde, tarih araştırmasının geçmiş olaylara ilişkin gerçeklere ulaşabilmek için konu ile ilgili kanıtların sistematik ve nesnel biçimde toplanması, değerlendirilmesi ve sentezlenmesi olarak tanımlandığ 1 görülmektedir (Borg, 1963). Tarih araştırmalarında genel olarak başvurulan iki tür veri kaynağından söz edilmektedir. İlki incelenen olgu, kişi ya da olayın ele alınan dönemdeki durumunu açı biçimde ortaya koyan birincil kaynaklardır. İncelenen bir nesne ise kendisi, kişi ise kendi ifadeleri, bir olaysa bununla doğrudan ilişkili belgeler ve fotoğraflardan birincil veri kaynakları olarak yararlanılabilmektedir. Birincil kaynaklara ulaşma olanağının bulunmadığı ya da bunların yetersiz olduğu durumlarda ikincil veri kaynakları işe koşulmaktadır. Bunlar genelde incelenen olgu, kişi ya da olaydan farklı, ancak ilişki içerisinde bulunmuş kaynaklardır. İnceleme nesnesine göre ilgili kişilerin yazılı/sözlü ifadeleri ya da ilişkili belgeler gibi kaynaklar bu grupta incelenebilmektedir (Cohen, Mannion ve Morrison, 2007; Frankel ve Wallen, 2009). 
Araştırmada birincil veri kaynağı olarak Prof. Dr. Alkan'ın personel dosyasında yer alan ve kendisi tarafından kaleme alınan özgeçmiş metni ve 1984 yılında yayımladığı "Eğitim Teknolojisi: Kavram Kapsam Süreç Ortam İşören Uygulama" kitabının sonunda yer alan "Yazarın Yapıtları" adlı bölümden; ikincil veri kaynă̆ olarak Prof. Dr. Alkan ile doğrudan ilişki içerisinde olmuş kişilerin sözlü ve yazılı ifadelerinden yararlanılmıştır. $\mathrm{Bu}$ süreçte Prof. Dr. Alkan'ın ailesi ve yakın çevresi ile görüşmeler gerçekleştirilmiştir. Yanı sıra araştırmacılar tarafından benzer bilimsel çalışmalar ve uzman görüşleri temel alınarak nitel bir anket formu geliştirilmiş ve kartopu örnekleme yöntemi ile belirlenen katılımcı gruba çevrimiçi olarak uygulanmıştır. Amaçlı örnekleme yöntemleri içerisinde ele alınan kartopu örnekleme yöntemi, araştırmanın başında araştırmacı tarafindan incelenen kişi ya da duruma ilişkin zengin bilgi kaynağı olabilecek katılımcıların belirlenmesine ve bu katılımcıların görüşlerine başvurularak belirlenen yeni kişilerle katılımcı listesinin genişletilmesine dayanmaktadır. Araştırmada kartopu örnekleme yönteminin işe koşulmasıyla ikincil veri kaynaklarından kaynaklanabilecek yanlış bilgi aktarımı ya da yanl111k gibi sorunların (Cohen, Mannion ve Morrison, 2007; Frankel ve Wallen, 2009) önüne geçilmeye çalışılmıştır. Elde edilen veriler içerik analiziyle çözümlenmiştir.

Çözümleme sürecinde veriler üzerinde gerçekleştirilen ilk incelemelerle temalara erişilmiş ve ayrıntılı incelemelerle temalar altındaki özellikler ve açıklamalar düzenlenmiştir (Yıldırım ve Şimşek, 2006). Araştırma sürecinde katılımcıların kartopu örnekleme gibi esnek bir yöntemle belirlenmesi, yanı sıra Prof. Dr. Alkan'ın kişisel ifadeleri, yakın çevresi ve çalışma arkadaşlarının sözlü ve yazılı ifadelerine başvurulmasının araştırmanın geçerliğini güçlendirdiği düşünülmektedir. Bununla birlikte geçerliği artırmak için temalar doğrultusunda ortaya çıkan bulgular ve bunlardan hareketle oluşturulan rapor, Prof. Dr. Alkan ile uzun yıllar çalışma olanağı bulmuş bazı öğrenci-meslektaşları tarafından gözden geçirilmiştir.

\section{BULGULAR}

\section{Kısa Yaşam Öyküsü}

Prof. Dr. Ömer Cevat Alkan 22 Aralık 1929 y1lında İstanbul yakınlarında doğar. Annesinin adı Makbule, babasının adı Ferhat'tır. Geçimini ormancılıktan sağlayan dört çocuklu bir ailenin en küçük ferdidir. Yaşadıkları köyde okul olmadığı için eğitim yaşamına iki yıl geç başlamak zorunda kalır. Okula başlama hikâyesi ise ilginçtir: Posta memuru olan eniştesinin daha büyük bir yerleşim birimine tayininin çıkması ile kendisi de eniştesi ve kız kardeşi ile birlikte bu yere taşınarak okula başlar. Sonrasında 
ilk ve orta öğrenimini eniştesinin tayin olduğu şehirler arasında dolaşarak tamamlar. Ülkenin yoksul yıllarında Anadolu'nun bir köşesinden diğerine yaptığı bu yolculuklar ve yolculukları sırasında edindiği izlenimler, Prof. Dr. Alkan'ın yaşamına kararlılık, çalışkanlık ve koşullar ne olursa olsun ülkeye hizmet etmede yılmazlık olarak yansıyacaktır.

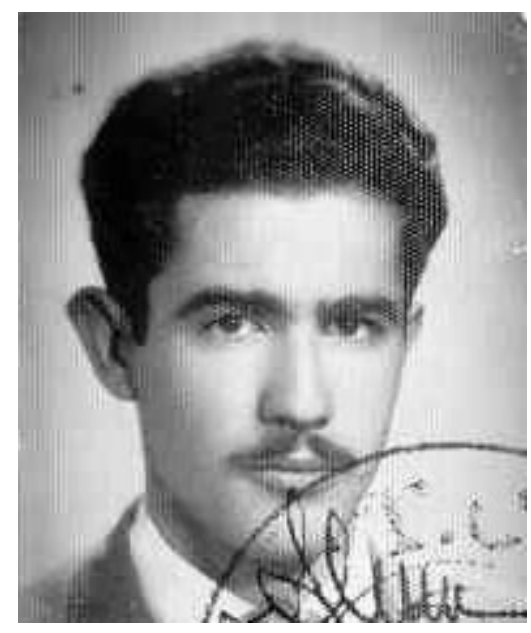

Öğretmenlik Yıllarl, Yozgat Sanat Enstitüsü, 1955

Ortaokuldan sonra Ankara Yap1 Sanat Meslek Lisesi'ni yatılı olarak kazanır. Sonrasında, 1955 yılında Ankara Erkek Teknik Yüksek Öğretmen Okulu'ndan (Gazi Üniversitesi Teknik Eğitim Fakültesi) mezun olur. 19551959 yılları arasında Yozgat Sanat Enstitüsü ve Erzurum Sanat Enstitüsü'nde öğretmen ve şef olarak beş y1l boyunca görev yapar. 1959 yılında Ankara Erkek Teknik Yüksek Öğretmen Okulu'nda asistan olarak çalışmaya başlar.

1965 yilında devlet bursu kazanarak Stout State Üniversitesi'nde Eğitimde Program Geliştirme alanında yüksek lisans (1965-1966) ve Ohio State Üniversitesi'nde Eğitim Felsefesi, Yükseköğretimde Yönetim, Öğretmen Yetiştirme ve Teknik Eğitim alanlarında doktora (1967-1969) öğrenimini tamamlar. 1966 y1lında tamamladığ 1 "The Proposed Curriculum for Training Woodworking Teachers for the Trade and Industrial Education in Turkey" adlı yüksek lisans tezinde; Türkiye'de Teknik Yüksek Öğretmen Okulu'nda yürütülmekte olan programları değerlendirerek, modern öğretmen yetiştirme yaklaşımları doğrultusunda geliştirme önerilerinde bulunur. 1969 yılında tamamladığı "A Proposed Cooperative Vocational Program for Trade and Industrial Occupation in Turkey" adlı doktora tezinde -kendi ifadesiyle "bilimsel ilkelere dayalı, işin eğitsel değerini ve eğitimin sosyo-ekonomik 
fonksiyonunu esas alan, Türk toplumunun özel ihtiyaçları ve koşullarına uygun bir iş-eğitim bütünlüğü eğitim sorunlarına en iyi çözümlerden biri olabilir" anlayışıyla- Türkiye'de eğitim sisteminin hizmet götüremediği genç kesime eğitim olanağ yaratacak işlevsel bir program geliştirir (Alkan, 1984: 225).

1970'de Türkiye'ye döner ve Ankara Erkek Teknik Yüksek Öğretmen Okulu'nda öğretmen ve müdürlük görevlerinde bulunur. 1972'de o dönemki adıyla Ankara Üniversitesi Eğitim Fakültesi Eğitim Programları ve Öğretim Bölümü'nde öğretim elemanı olarak çalışmaya başlar. 1975 yılında "Eğitim Teknolojisi" adlı tezle üniversite doçenti, 1983 yılında "Açık Üniversite" adlı tezle profesör olur. Şubat 1996 tarihinde Ankara Üniversitesi Eğitim Bilimleri Fakültesi'nden emekliye ayrılır. Akademik çalışmalarının yanı sıra 1978-1979 yıllarında Milli Eğitim Bakanlığı'nda Mesleki ve Teknik Öğretim Müsteşarlığı görevini de yürütür (Milli Eğitim Bakanlığı, 2012).

Çeşitli ülkelerin eğitim sistemleri üzerine incelemelerde bulunur, konuk öğretim üyesi olarak görev yapar, eğitim teknolojisi ve açı öğretim konularında ulusal ve uluslar arası eğitim projelerine katılır. 1984 yılında Milli Eğitim Gençlik ve Spor Bakanlığı Orta Öğretimde Bilgisayar Eğitimi İhtisas Komisyonu'nda görev alır. Çeşitli ülkelerin eğitimde bilgisayar uygulamalarını inceleyerek Türkiye'nin bu doğrultudaki rotasını belirlemek amacıyla bir araya gelen bu komisyonun hazırladığı rapor, Türkiye'de gerçekleştirilen eğitimde bilişim teknolojileri uygulamaları için bir temel oluşturmuştur.

Türkiye, Balkanlar, Avrupa ve Amerika Birleşik Devletleri'nde düzenlenen çeşitli ulusal ve uluslar arası bilimsel toplantılara katılır, bildiriler sunar ve toplantılar yönetir. İlk kez Türkiye'de bir Ulusal Eğitim Bilimleri Kongresi düzenleme fikrini ortaya atar. Bu doğrultuda Ankara Üniversitesi Eğitim Bilimleri Fakültesi'nde kendi oluşturduğu ekibiyle birlikte 24-28 Eylül 1990 tarihinde Eğitim Bilimleri Birinci Ulusal Kongresi'ni düzenler. Düzenleme faaliyetleri içerisinde başından sonuna kadar bizzat yer alır ve bu kongrenin bildiri kitabını da beş cilt olarak hazırlar ve yayımlatır. Prof. Dr. Alkan'ın yaktığı meşale 2011 yılı itibariyle 20. si düzenlenen Ulusal Eğitim Bilimleri Kongresi, beşincisi onun adına düzenlenen Uluslararası Bilgisayar ve Öğretim Teknolojileri Sempozyumu ve yanı sıra ülkemizde eğitim bilimlerinin hemen her alanında düzenlenen kongrelerle yaşatılmaktadır.

Uzun süre Teknik Öğretmenler Derneği Genel Başkanlığı'nı yürütür, Eğitim Araştırmaları Derneği, Mesleki ve Teknik Eğitimi Geliştirme Derneği, World Association for Educational Research (WAER) ve The World Council of Curriculum and Instruction (WCCI) gibi mesleki kuruluşların üyesi olur ve üç dönem UNESCO Milli Komisyonu, Eğitim İhtisas Komitesi üyesi olarak çalışır. 
10 Temmuz 2007 tarihinde aramızdan ayrılan Prof. Dr. Alkan arkasında yetiştirdiği pek çok biliminsanının yanı sıra; 12 araştırma ve inceleme, 21 kitap, 31 bildiri ve 40 makale olmak üzere 104 telif eser; 5 kitap ve 9 makale olmak üzere 14 çeviri eser; ayrıca çeşitli gazete yazıları, radyo ve televizyon konuşmaları bırakmıştır. Evli ve iki çocuk babasıdır.

\section{Eğitim Teknolojisi Alanına Katkıları}

Prof. Dr. Alkan Türkiye'de eğitim teknolojisi alanında çalışmalar yürüten ilk biliminsanıdır. Eğitim Teknolojisi Anabilim Dalı'nın Türkiye'deki kurucusudur. Eğitim Bilimleri Fakültesi'nde göreve başladığı tarihten itibaren eğitim teknolojisi alanında, yanı sıra eğitim felsefesi ve mesleki ve teknik eğitim alanlarında dersler vermiş ve tez çalışmaları yürütmüştür.

1970’li yıllarda Eğitim Programları ve Öğretim Bölümü'nde üçlü bir yapılanma söz konusudur. Bölüm içerisinde eğitim teknolojisi alanındaki etkinlikleri Prof. Dr. Alkan, mesleki ve teknik eğitim alanındaki etkinlikleri Prof. Dr. Hıfzı Doğan ve eğitimde program geliştirme alanındaki etkinlikleri Prof. Dr. Fatma Varış üstlenmiştir. 1981 yılından itibaren eğitim teknolojisi ve mesleki ve teknik eğitim alanlarına ilişkin bilimsel etkinlikler Teknik Eğitim Bölümü adıyla Eğitim Programları ve Öğretim Bölümü’nden ayrılır. Bu tarihten sonra Prof. Dr. Alkan Teknik Eğitim Bölümü içerisinde mesleki teknik eğitim ve eğitimde program geliştirmenin yanı sıra yine ağırlıklı olarak eğitim teknolojisi alanında bilimsel çalışmalarını ve derslerini sürdürür. 1987 yılında Teknik Eğitim Bölümü'nün kapatılmasının ardından Prof. Dr. Alkan Eğitim Programları ve Öğretim Bölümü içerisinde Eğitim Teknolojisi Anabilim Dalı'nı kurar ve emekli olduğu 1996 yılına kadar anabilim dalı başkanlığg görevini sürdürür. 


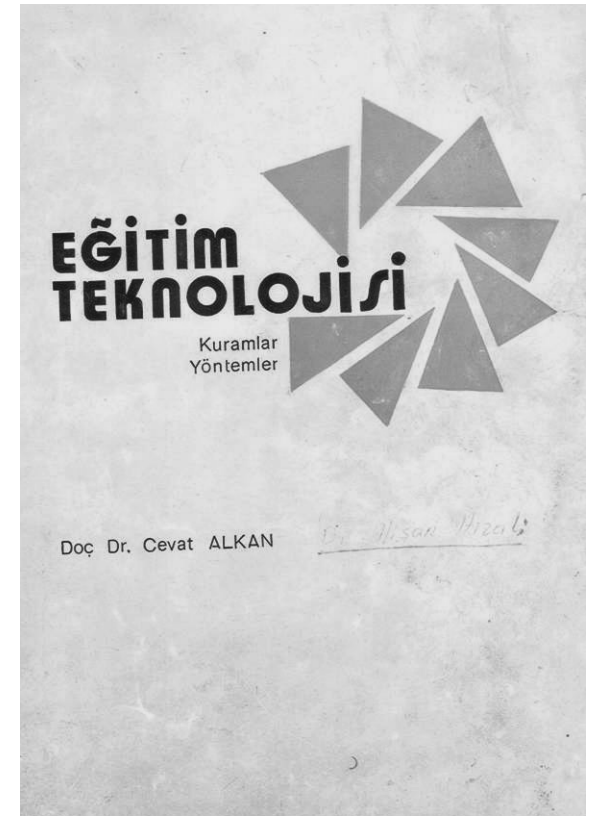

Illk Türkçe Eğitim Teknolojisi Kitabl, 1977

İlk Türkçe eğitim teknolojisi kitabını yazar. Eğitim Bilimleri Fakültesi'nde ders vermeye başladığı 1972 yılından itibaren, öğrenci taleplerine koşut olarak, bu konuda Türkçe kaynak gereksinimi ortaya çıkar. Prof. Dr. Alkan bu gereksinim doğrultusunda ders notu olarak ortaya koyduğu çalışmalarını 1977 yılına değin geliştirir ve "Eğitim Teknolojisi: Kuramlar ve Yöntemler" adıyla kitap olarak yayımlar. Kitabın önsözünde eğitim teknolojisi disiplinine olan ihtiyacı şu tümcelerle ortaya koyar:

“...Eğitimi bir bilim olarak inceleme ve araştırma konusu yapmak bugün için ne kadar gerekli ve doğalsa, bu bilimi en etken biçimde uygulamaya dönüşürmek üzere gerekli inceleme ve araştırmalar yapmak ve bu maksatla bir teknoloji gelişstirmek de aynı derecede önemli ve zorunlu bir husustur. Çünkü bilim ve teknoloji bir bütündür. Teknolojisiz bilim kuramsal düzeyde kalmakta, bilimsiz teknoloji ise ilkel düzeyden öteye gidememektedir... Eğitimde bu gerçeğin anlaşılabilmesi için aradan yüzyılların geçmesi; uzay yarışı, dünya savaşları, nüfus patlamasl, bilgi patlamasi gibi olaylartn meydana gelmesi ve toplumların bir eğitim krizi ile karşılaşması gerekmiştir. Ancak, bu olaylar sonucundadır ki bugün eğitimi, teknolojik yönden 
ilkel düzeyden çağdaş düzeye çıkarma, ĕgitimde yeni teknolojiler geliştirme çabalarına tanık olunmaktadır. Çağımızın devrimsel nitelikleri ve hızlı değişmeleri, eğitim alanında bir yandan yeni olanaklar yaratırken diğer yandan yeni ve ciddi sorunlara yol açmaktadır. Değişen koşullar herkes için daha iyi ve daha fazla eğitimi gerektirmektedir. Bugünün eğitim sistemleri bireyleri daha iyi yetiştirmek, toplumun sosyal ve ekonomik yönden daha güçlü ve mutlu hale getirilmesi için daha kaliteli eğitim sağlamak ve eğitimde firsat eşitliğini gerçekleştirmek gibi sorunlarla karşı karşıya bulunmakta, her zamankinden daha karmaşık görevleri yerine getirmek sorumluluğunu taşımaktadır... Bu koşullar altında eğitim, kuramsal temelleri yeniden değerlendirmek, yapısını yeniden organize etmek, programların yenilemek, yeni yöntem ve süreçler gelişstirmek zorunda kalmaktadır... Eğitim alanında yapllmakta olan bu yeniliklerin ve alınan tedbirlerin genel çerçevesi içinde eğitim teknolojisinin yerini incelemek gereği doğaldır. Bu çalışmalarda öğrenme-ögretme süreci üzerinde durulmast, öğretmen, araç-gereç ve öğrenci etkileşimlerinin dikkate alınması, eğitim zamanının gereklerine uydurulması, sayısal ve yapısal değişiklik anlayışı üzerine yenilik yapılması, eğitimde kalitenin yükseltilmesi ve etkenlik yönünden gereklidir" (Alkan, 1977: III-V).

Dört kısım ve on bölümden oluşan kitabın birinci kısmında Prof. Dr. Alkan toplumsal değişimleri ve bu değişimlerin eğitim anlayışında yarattı̆̆ sorunları gelişmiş ülkeler ve Türkiye bağlamında ele almaktadır. Yanı sıra eğitimde yeni bir teknoloji gereğini, teknoloji-eğitim ilişkisi ve teknolojik gelişmelerin yarattığı olanaklar bağlamında tartışmaktadır. İkinci kısımda, kuramsal temelleriyle eğitim teknolojisi disiplinini tanımlamaktadır. $\mathrm{Bu}$ doğrultuda öğretme-öğrenme sürecini sistem yaklaşımıyla irdeleyerek, eğitim sürecini etkileyen farklı sistemler doğrultusunda eğitim teknolojisinin araştırma alanlarını ortaya koymaktadır. Üçüncü kısımda, eğitim teknolojisinin uygulama alanlarını televizyonla öğretim, bilgisayarla öğretim, yabancı dil laboratuarları, programlı öğretim ve Türkiye'de eğitim teknolojisi uygulamaları boyutlarıyla incelemektedir. Dördüncü ve son kısımda ise, dünyada ve Türkiye'de toplumsal, ekonomik ve teknolojik değişimlerin eğitim anlayışı ve eğitim sistemlerine etkileri, bu etkiler doğrultusunda gelişen eğitim teknolojisi disiplini ve eğitim alanındaki yansımalarını bütüncül bir anlayışla tartışmakta ve eğitim uygulamaları ve araştırmalarına dönük önerilerde bulunmaktadır. Prof. Dr. Alkan kitabını 
yıllar içerisinde alandaki değişimleri gözeterek beş kez güncellemiştir. "Eğitim Teknolojisi" adıyla sekizinci baskısı 2011 yılında yapılan kitap Türkiye'de eğitim teknoloji alanında en yaygın eserdir.

Prof. Dr. Alkan'ın eğitim teknolojisi alanında bir diğer önemli kitabı 1979 yılında yayımlanan "Eğitim Ortamları'dır". Eğitim ortamı ve bu ortamı etkileyen unsurları kuramdan uygulamaya geniş bir bakış açısıyla ele alan çalışma, eğitim ortamlarını öğretme-öğrenme süreçleri ve etkileşim, eğitim personeli, teknoloji kaynakları ve organizasyon-yönetim boyutlarıyla ele almaktadır. Bir diğer önemli kitabı 1987 yılında yayımlanan "Açıöğretim: Uzaktan Eğitim Sistemlerinin Karşıllaştırmalı Olarak İncelenmesi'dir". Beş bölüm halinde yapılandırdığı çalışmasında Prof. Dr. Alkan, açıköğretimi öğrenci, program, yönetim, personel, tesis, finansman, destek hizmetleri, alt yapı, ilgili kurumlar ve öğretim süreçleri bağlamında ele almakta ve dünyada farklı uygulamaları karşılaştırmalı biçimde incelemektedir. Diğer bir önemli çalışması 1992 yılında Necmettin Teker ile birlikte hazırladığı "Programlı Öğretim: Değişik Teknolojiler ve Türkiye'deki Uygulama'dır". Üç bölümden oluşan kitapta programlı öğretim ve modüler öğretim yaklaşımları kuramsal temeller, program yapıları, teknolojik olanaklar ve Türkiye'deki durum gibi boyutlarla ele alınmakta ve yazarlar tarafından geliştirilen uygulama örnekleri sunulmaktadır. Eğitim teknolojisi alanında yayımlanan bir diğer önemli kitabı Deniz Deryakulu ve Nurettin Şimşek ile birlikte 1995 yılında kaleme aldığı "Eğitim Teknolojisine Giriş: Disiplin Süreç ve Ürün" adlı çalışmadır. Eğitim teknolojisi alanını çağdaş gelişim boyutlarıyla tanıtmayı amaçlayan bu kitapta, bir disiplin olarak eğitim teknolojisi ve eğitim teknolojisini oluşturan unsurlar; eğitim teknolojisi kavramının gelişim süreci, öğretme-öğrenme süreçleri, nesnel ve yapıcı öğretme-öğrenme anlayışları; yanı sıra eğitimde bilgisayar, televizyon, uydu, etkileşimli video ve hipermetin gibi yeni teknolojiler üzerinde durulmaktadır. Alanda önemli yere sahip olan bir kitabı da Mehmet Kurt ile birlikte hazırladığı ve 1998 yılında yayımlanan "Özel Öğretim Yöntemleri: Disiplinlerin Öğretim Teknolojisi'dir”. Öğretim sürecini öğrenme yaşantılarının planlaması, kavram öğretimi, motor yetenekler, alışkanlık geliştirme, öğrenme için güdüleme gibi temel esaslar ve çağdaş eğitim teknolojisi bağlamında ele alan çalışmada ayrıca; fen bilimleri, sosyal bilimler ve yabancı dil öğretimi süreçlerine ilişkin öğretim teknolojileri de incelenmektedir. Prof. Dr. Alkan'ın eğitim teknolojisi alanının yanı sıra mesleki ve teknik eğitim ve eğitim felsefesi alanlarında da kitapları bulunmaktadır. Başlıca eserleri araştırmanın sonunda listelenmiştir (Bakınız: EK 1). 
Prof. Dr. Alkan eğitim teknolojisi alanında lisansüstü düzeyde dersler veren ilk biliminsanı olur ve yine eğitim teknolojisi alanında doktora öğrenimini Türkiye'de tamamlayan ilk biliminsanını (Prof. Dr. Alişan Hızal) yetiştirir. Görev yaptığı süre içerisinde Türkiye'de eğitim teknolojisi alanının bir anabilim dalı olarak gelişmesine, bu doğrultuda lisans ve lisansüstü düzeyde ders programlarının geliştirilmesine öncülük eder. Hacettepe, Uludağ, Anadolu, Malatya İnönü ve Abant İzzet Baysal Üniversitesi'nde eğitim teknolojisi, eğitim felsefesi, teknik eğitimin prensipleri, eğitime giriş, eğitimde program geliştirme, eğitim araçları, eğitim teknolojisinde kuramlar ve yöntemler, eğitim teknolojisinde uygulama, eğitim ortamlarının kullanımı, okul atölyelerinin organizasyonu ve yönetimi, eğitim teknolojisinde iletişim, eğitim teknolojisinde araştırma sorunları, analiz ve program geliştirme, eğitim teknolojisinde seminer, uzaktan öğretim, özel öğretim ilke ve yöntemleri, teknik eğitimin kuramsal temelleri, genel ve teknik eğitim programlarının dengelenmesi, çağın teknolojik özellikleri, disiplinlerin öğretim teknolojisi, eğitim teknolojisinde eğitici personel yeterlikleri, eğitimde ergonomik sorunlar ve benzeri dersleri okutur. Pek çok yüksek lisans ve doktora tez çalışması yürütür, tez jürilerinde görev yapar. Yanı sıra yardımcı doçentlik, doçentlik ve profesörlük jürilerinde yer alır.

\section{Biliminsanı Özellikleri}

Katılımcıların en çok üzerinde durduğu özellik Prof. Dr. Alkan'ın çalışma disiplinidir. Prof. Dr. Alkan öğrencileri tarafindan her zaman titiz, planlı ve yoğun çalışan bir biliminsanı olarak tanınırdı. Bilimsel düşüncelerinde tutarlı idi. Bilimsel bakış açısından ve analitik düşünceden ödün vermezdi. Bununla birlikte sürekli gelişime açıktı. Çalışmalarında, seminerlerinde, lisansüstü derslerinde her zaman çok boyutlu bakış açıları geliştirmeye ve olayların, olguların farklı yönlerini ortaya çıkarmaya özen gösterirdi. Bir öğrencisi bu durumu “...hiçbir zaman, hiçbir çalışmanın son noktası ya da bitimi olmayacağını söylerdi” biçiminde açıklamaktadır.

Çok okuyan, kuramsal yönü oldukça güçlü bir akademisyendi. Hafta sonları asistanlarına ödev vermeyi adet edinirdi ve o dönemki asistanlarının tabiriyle onlara verdiğinin en az üç katı sorumluluğu da kendisi üstlenirdi. Buna rağmen çevresindekiler kendi sorumluluklarını yerine getiremeseler bile, hoca hep işini tamamlardı. Bir öğrencisi bu duruma ilişkin olarak “...hocanın hızına ve kalitesine asla erişilemezdi" demektedir. Prof. Dr. Alkan'ın yoğun çalışma temposuna ilişkin olarak, Eğitim Teknolojisi Anabilim Dalı'nda uzun yıllar birlikte çalıştığı bir öğrencisi bir anısını şu biçimde aktarmaktadır: 
“...1980’li yillartn sonuydu. Cevat Hoca önemli bir göz ameliyatı geçirmişti ve bir süre hastanede kalması gerekiyordu. Biz de Akif Hoca, Necmettin Hoca ve ben, hocanın fakültedeki işlerini üstlenip aramızda paylaşmıştık. Görevimiz her gün işleri düzenli biçimde takip edip, o günün akşamında hocaya hastanedeki odasında rapor vermekti. Bana teknik eğitimle ilgili derslerin yürütülmesi görevi düşmüş̧ü. Ancak, programı elime alıp da bana düşen işin yoğunluğunu incelediğimde hocanın sadece teknik ĕgitim alanında farkl sinfflarda sekiz ders vermekte olduğunu gördüm. Hocanin derslerini tamamlamak, sinavlarını hazırlamak ve değerlendirmek için gecelerce uykusuz kaldığımı bilirim. Sonra arkadaşlarımla konuşunca gördük ki bu kadar uğraşmamıza rağmen işleri tam anlamıla yetiştiremiyoruz, yani üç kişi bir Cevat Hoca etmiyoruz. Hoca da bu sırada hem hastalığıyla uğraşıyor, hem bizim raporlarımızı dinleyip işleri düzenliyor hem de refakatçi olarak yanında kalan Mehmet Emin'in doktora tezini okutup düzeltiyordu."

Prof. Dr. Alkan, alandaki yenilikleri her zaman yakından izler ve farklı, özgün çalışmalara daima öncülük ederdi. Bu yönü sayesinde yetiştirdiği pek çok biliminsanı eğitim teknolojisinin farklı ve yeni alanlarında uzmanlaşabilme olanağı bulmuştur.

Prof. Dr. Alkan'ın diğer önemli bir özelliği olarak da, meslek sevgisi ortaya çıkmaktadır. Bir öğrencisinin tabiriyle hoca akademisyenliği "yaşam felsefesi" olarak kabul etmiştir. Bir öğrencisi bu duruma örnek olarak YÖK öncesi üniversite ve akademi ayrımının yapıldığ 1 yıllarda bütün bir yıl tüm hafta sonları Cevat Hocanın bıkmadan yorulmadan Ankara'dan farklı illere ders ve seminer vermeye gitmesini göstermektedir. Bir diğer önemli özelliği olarak da bilimsel azmi üzerinde durulmaktadır. Öyleki, başarılmazları başaran olarak tanınmıştır. Bir öğrencisi bu konuda şunları dile getirmektedir:

“...Cevat Alkan’ı ben Amerika'da düşünmüşümdür. Up to sky (sınırsız) bir bütçe eline verilmiş olsaydı diye. Son derece sinırlı olanaklarla başarllmazları başaran... Sanıyorum Türk Eğitim Sistemi'nin temel taşlarını oynatırdı". 


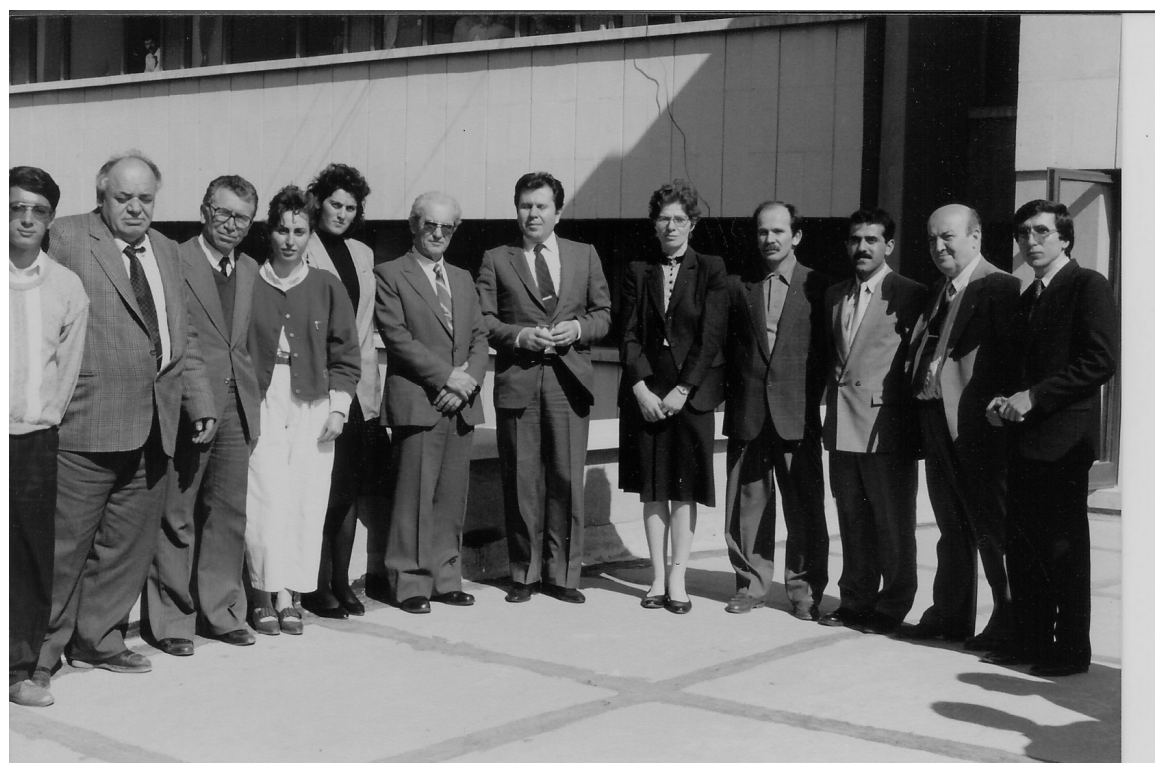

Prof. Dr. Alkan Eğitim Bilimleri Fakültesi'nden ögrretim üyeleri ile birlikte. Ĕ̈itim Bilimleri Birinci Ulusal Kongresi, 1990

Prof. Dr. Alkan öğrencileri tarafından oldukça ileri görüşlü bir hoca olarak tanınmaktadır. Hoca eğitim teknolojisinin geleceği ve gelecekte sahip olacağ 1 önem konusunda son derece isabetli öngörülere sahipti. Konferans, panel ve konuşmalarda bu doğrultuda sorular sorar, katkılar sağlardı. Öğrencilerinin tabiriyle eğitimle ilgili tüm toplantılarda sözü bir şekilde eğitim teknolojisine bağlar ve bu konuda bir "korsan bildiri" muhakkak sunardı. Prof. Dr. Alkan'ın teknolojik gelişmelerin eğitim alanına etkilerine ilişkin öngörüleri konusunda bir öğrencisi şu anısını aktarmaktadır:

“...Yll 1974. Cevat Bey Hocam ders anlattyor...

- Arkadaşlar bir gün gelecek ki, o günler yakın, telefonla görerek konuşulacak, ögrenciler okula çanta götürmeyecekler.

-Ya ne götürecekler hocam?

- Cep bilgisayar. Aynı zamanda kitalararası görüntülü dersler ve tartışmalar...

Ardindan yıllar geçmiş. Sakarya'da Eğitim Teknolojileri Kongresi. Cevat Bey Hocam rahatsız, refakatle kongreye katıllyor. Bir oturumda Amerika'dan bir sunu var. Sunu görüntülü ve canl. Ara verildi oturuyoruz, hoca şöyle dedi: 
- Mustafa hatırlarsan ben size 74'te bunları anlatmıştım ve tartışmıştık...

Hocam o koşullarda bile bana 26 yll öncesini hatırlatarak bilimsel gücü ve öngörüsüyle son dersini vermişti."

\section{Öğreticilik Özellikleri}

Cevat hoca denince, öğrencilerin çoğunlukla üzerinde durduğu nokta hocanın tatl1-sert üslubudur. Eski öğrencileri arasında şöyle bir espri dolaşırdı: "Hoca bu gün bana kızmadl, yoksa artık beni sevmiyor mu?" Prof. Dr. Alkan derslerinde ve seminerlerinde oldukça eleştirel bir yaklaşım sergilerdi. Bu gün değerli bir akademisyen olmuş eski bir öğrencisi bu durumu şu biçimde ifade etmektedir:

“...Akademik yaşamımın ilk yıllarında birlikte çalışma olană̆ı bulduğum hocamdan hep çekinmişimdir. Herhangi bir konuda eleştiriye maruz kalma kaygısı yaşamıı̧ımdır. Ancak, bunun hep daha iyisini istemenin bir sonucu olduğunu daha sonra anlayabilmişimdir."

Prof. Dr. Alkan bu yönüyle öğrencilerini hep daha çok düşünmeye, araştırmaya ve daha çok gelişmeye yönlendirirdi. Zor beğenen hoca olarak bilinirdi. Çalışmaların niteliği konusunda zorlayıcı bir tutum sergilerdi. Zaman zaman isteklerinin sonu gelmezdi. Pek çok öğrencisi hocanın bu yönünün yararlarını sonraki meslek yaşamlarında gördüklerini belirtmektedirler. Bir öğrencisi bu durumu şu biçimde aktarmakta:

“...Öğrencisini son noktaya kadar sikıp potansiyelini ortaya çıkarmada kendine has, özgün bir yöntemi vardl. Hiçbir zaman, hiçbir çalışmayı mükemmel ve bitmişs olarak kabul etmemesi sayesinde insanı sürekli gelişmekte tutardl."

Öğrencilerinin hepsini öğrenme sürecine katmaya çalışırdı. Öğrencileri onu demokratik öğretim ortamını gerçekleştiren ender hocalardan biri olarak nitelemektedir. Bir öğrencisi bu özelliğine ilişkin şunları söylüyor:

“...Lisans derslerinde hoca sinifi gruplara ayırır, bir grubu da değerlendirme grubu olarak seçerdi. Tüm gruplar ve gruplar içerisindeki tüm bireyler çalı̧̧malar gerçekleştirir, sonrasinda değerlendirme grubu sunum yapan grubu değerlendirirdi. Ancak, bu öyle bir değerlendirmeydi ki sadece sunumun içeriğ $i$ 
üzerinde durulmazdl. Sunum yapanların üslubu, klyafetleri, zamanı kullanma becerileri hep bu değerlendirmenin konusu olurdu."

Eleştirel düşünceye önem verir, her öğrencisinde bu yetiyi geliştirmeye çabalardı. Bir öğrencisi bu durum hakkında şunları söylemektedir:

“...Hoca soru sorduğunda, söz verdiğinde asla arkadaşımın söylediklerine katılyyorum biçiminde bir cevabı kabul etmezdi. Onun fikrini bırak, sen ne düşünüyorsun derdi."

Mütevazı, mesafeli bunun yanında kucaklayıcı bir kişiliği vardı. Öğrenci ürünlerine büyük sayg1 duyardı. Tüm ödevleri zamanında değerlendirir ve en can alıcı noktalarını kapsayan dönütler verirdi. Öğrencinin sorgulayıcı olmasına saygı duyar, hatta özendirirdi. Yüksek bir güdüleme gücü vardı. Çeşitli ve farklı yöntemlerle öğrencilerin çalışmaktan zevk almasını sağlardı. Son derece vericiydi. Sadece bilgisini, bakış açısını paylaşmakla kalmazdı. Bazen çantasında olan bir elmayı da öğrencileriyle paylaşırdı. Bir öğrencisi bu konuda şunları aktarıyor:

“...Yüksek lisans derslerine gelirken çantasında hep bir şeyler getirirdi. Grup sıklldı̆̆nda bazen bir elma, bazen bir simit çıkarır ve hemen sıkıntılı havayı dağıtırdı."

Prof. Dr. Alkan yetiştirdiği biliminsanını, sadece bilgi ve becerilerle donatmakla kalmaz, aynı zamanda bilimsel bir bakış açısı ve terbiye de kazandırmaya özen gösterirdi. Bu bakış, çalışma alışkanlıklarından-insan ilişkilerine, giyim kuşamdan-hayat tarzına kadar geniş bir yelpazeyi kapsard1. Bu gün çok değerli hocalar olan Prof. Dr. Alkan'ın eski öğrencilerinde bu ortak özellikleri hala görmek mümkündür. Eski bir öğrencisi bu durumu şu biçimde ifade etmektedir:

“...Cevat Hocamızın asistanı olmak çok zor, ama bir o kadar da zevkliydi. O mazeret kabul etmeyen işine kendisini adamıs ögrenciler isterdi. Zaten öyle olmayan ögrencilerin onunla çalışması neredeyse imkânsızd. Nitekim onun rahle-i tedrisinden geçmiş olan değerli hocalarımızda da Cevat Hocamızın izlerini görmek oldukça mümkündür." 


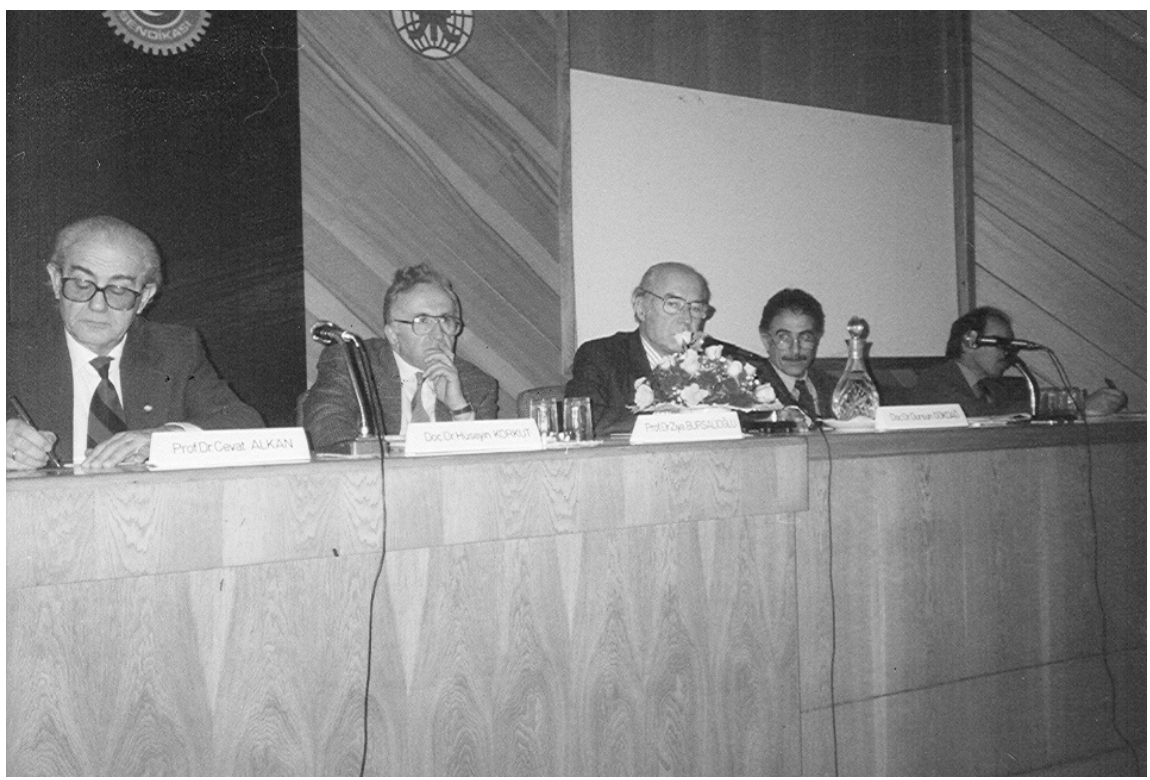

Prof. Dr. Alkan bilimsel bir toplantıda, Ankara, 1990'lar

Prof. Dr. Alkan'ın önemli bir yetiştiricilik özelliği de öğrencisine güvenmesi ve bunu hissettirmesi idi. Bu duygu öğrencilerini daima daha büyük işlere girişmek için güdülerdi. Bir öğrencisi hocayı bu yönüyle "insan yetiştirme mühendisi" olarak tanımlarken, diğer bir öğrencisi hocanın kendisine kazandırdığı bu özgüvene ilişkin şöyle bir anısını paylaşmaktadır:

“...Merkez Bankası Eğitim Müdürlüğ̈̈, Ĕgiticilerin Eğitimi Programın düzenleyecekti. Sunum teknikleri konusunda Cevat Hocamızı davet etmek istemişlerdi. Eğitim Müdürlüğ̈̈ Müdürü Cevat Hoca ile konuşup kendisini davet ettiğini bildirmişti. Cevat Hocam ise -sizde bir ögrencim var, bu dersi o verebilirdiye derse hoca olarak beni önermişti. Hocamın bu davranışı beni çok onurlandırmıştı. O dersin notlarını hazırlarken üzerimde çok büyük bir sorumluluk hissetmiştim."

\section{Kişilik Özellikleri}

Prof. Dr. Alkan denince öğrencilerinin hemen hepsinin üzerinde birleştiği özelliği, önceki bölümlerde de ifade edilen, tatl1-sert mizacı idi. Onunla çalışan herkes hocanın bu yönünü bilir, hocadan çekinirdi. Ancak, bu sertlik karşısında kırılmaz, incinmezdi. Uzun yıllar birlikte çalıştığı bir 
öğrencisi bu durumu şu sözlerle özetlemektedir: "Hocadan önce korkarsınız, sonra bağımlılık yapar."

Prof. Dr. Alkan'ın önemli bir kişilik özelliği öğrencilerini çocukları gibi benimseyip yaşam sorunlarını önemsemesiydi. Öğrencilerini sıkı çalıştıırı̀ı çalıştırmasına, ancak yetiştirdiği biliminsanlarının yaşamın diğer yönlerini de ihmal etmemesini ister, ögrencilerini bu doğrultuda da gözetir ve güdülerdi. Bir öğrencisi buna ilişkin bir anısını aktarmaktadır:

“...Hoca küçük bir çocuğa sahip olarak doktora yapmanın zorluklarını bilerek bana sık, sık -çocuğunla da ilgilenebiliyor musun?- diye sorardl. O günlerde tesadüf ben çocuğumu gezdirirken Kuğulu Park'ta Hafize Hocamla karşılaşmıştık. Hocanın yine bu soruyu sorduğu bir gün Hafize Hoca benim çocuğumla yakından ilgilendiğimi, kendisinin bu duruma şahitlik ettiğini söyledi. Cevat Hoca bu konuda güvenilir ve doyurucu bilgi aldığ için bana bir daha çocuğumla ilgilenmem konusunda telkinde bulunmadl."

Prof. Dr. Alkan yetiştirdiği insanların yaşamlarının bir köşesinde değil, tam merkezindeydi. Asistanına kız istenecekse hoca ister, nikâh şahitliği yapilacaksa hoca yapar, birine bir hediye alınacaksa herkesten önce hoca katk1 yapar, bir asistanı ya da öğrencisinin paraya ihtiyacı olduğunda sorunu sessiz sedasız biçimde hoca çözerdi. 1990'lı yıllarda asistanlığını yapmış bir öğrencisi bu duruma ilişkin şöyle bir anısını aktarmaktadır:

”... Göreve başladı̆̆ım ilk aylardl. Bu arada yüksek lisansa da devam ediyordum. Yüksek lisansta her hocadan bir dönem ödevi hazırlyyorduk. Ama Cevat Hoca'dan her hafta ödev hazırlyyorduk. Yll 1993 'ün sonu. Bireysel olarak bir bilgisayara sahip olmak o yıllarda hele göreve yeni başlamış bir asistan için neredeyse mümkün değil. Yaptı̆̆ımız ödevlerinde çıtıtısını fotokopicilerden alıyor ve kazandiğımı parayı oralara akitıyorduk. Cevat Hoca'ya bilgisayar alma konusunu açtım ve taksitle bilgisayar almak istediğimi söyledim. Hoca -bilgisayar ve yazıcı fiyatların araştır gel-dedi. Asistan arkadaşım Mustafa ile toplama bir bilgisayar ayarladik. O zaman bilgisayarlar döviz üzerinden satıllyordu. Cevat Hoca mark olarak bilgisayarın parasının tümünü bana verdi ben de her maaş aldığımda kendisine 200 mark ödeyerek bir yılda borcumu kapattım. Ben bilgisayar aldıktan sonra bir asistan arkadaşım daha hocadan dolar borç alarak bilgisayar almıştı. Bu olaydan 
sonra benim adım Markçı arkadaşımın adı da Dolarcı'ya çıkmışıt. Hatta Dolarcı arkadaşım ev taşıdığı için Hoca ondan son taksit olan 100 dolarl almamış -o para senin ev hediyen olsun- demişti."

Prof. Dr. Alkan, özel hayatında mütevazı bir yaşamı tercih ederdi. Dengi hocaların daha lüks otomobillere bindiği yılarda Murat 124'e binerdi. Ancak meslektaşlarından, öğrencilerinden kimin işi düşse arabasını vermekten asla çekinmezdi. Zaman zaman, asistanları onun arabasıyla küçük kazalar yapar, ancak akademik anlamda sert bilinen Cevat hoca bu tip şeylere asla kızmadı. Kendisi öğünlerini bazen bir sandviçle geçiştirir, ama çalışma arkadaşlarını en iyi restoranlara götürmekte tereddüt etmezdi. Hocanın bu özellikleri sayesinde onunla lisansüstü çalışmalar yapan öğrencileri ve asistanları kendilerini hep büyük bir ailenin parçası gibi hissederlerdi.

Prof. Dr. Alkan öğrencileri ve meslektaşları tarafından dakikliği ile tanınırdı. Toplantılarda her zaman en önce o hazır bulunur, derslerine daima tam zamanında gelirdi. Mesleki yaşamında sadece bir kez bir final sınavına geç kaldığı hatırlanır. Bir öğrencisi bu olaydan anımsadıklarını şöyle özetlemektedir:

“...1972-1973 öğretim yllıydl. Hocadan eğitim yönetimi bölümüyle birlikte 25-30 kişilik kalabalık bir grup olarak Eğitim Araçları dersini alıyorduk. Hoca o gün sinav olacağını önceden duyurmuştu. Biz de kendisinin dakikliğini bildiğimizden erkenden sinıfta toplandık ve beklemeye başladık. Vakit geçtikçe şaşırıyorduk, zira hiçbir işine gecikmeyen Hocamız sinava geç kalmıştı. Ancak bu konudaki titizliğini bildiğimizden çok acil bir işi olmasa asla geç kalmazdı diyerek, odasına ya da dekanlığa gitmeden sessizce bekledik. Yaklaşık 45 dakika sonra hoca geldi. Hiçbir açıklama yapmaksızın soruları yazdırıp sinavını başlattl ve hemen sinifi terk etti. Çok garipsememize rağmen içimizden kimse bunun sebebini soramiyordu. Biraz sonra yanında kat görevlisi ve kolilerle geri geldi. Önce her birimizin önüne, peçete yerine, önceden hazırladiğ yarım teksir kâğıtlarını yerleştirdi. Sonra kendi eliyle bizlere meyve suyu, poğaça ve kurabiye ikram etti. Ve şöyle dedi:

- Çocuklar, hayatımda ilk kez bir sinava geç kaldım. Aslında zamanında gelmiştim. Ancak, tam okulun kapısından girerken sizlerin kahvaltı yapmadan gelmiş olabileceğinizi düşünüp kahvaltılık bir şeyler almak için geri döndüm.

Hocanın bundan başka bir yere geç kaldı̆̆ına hiç şahit olmadlk..." 


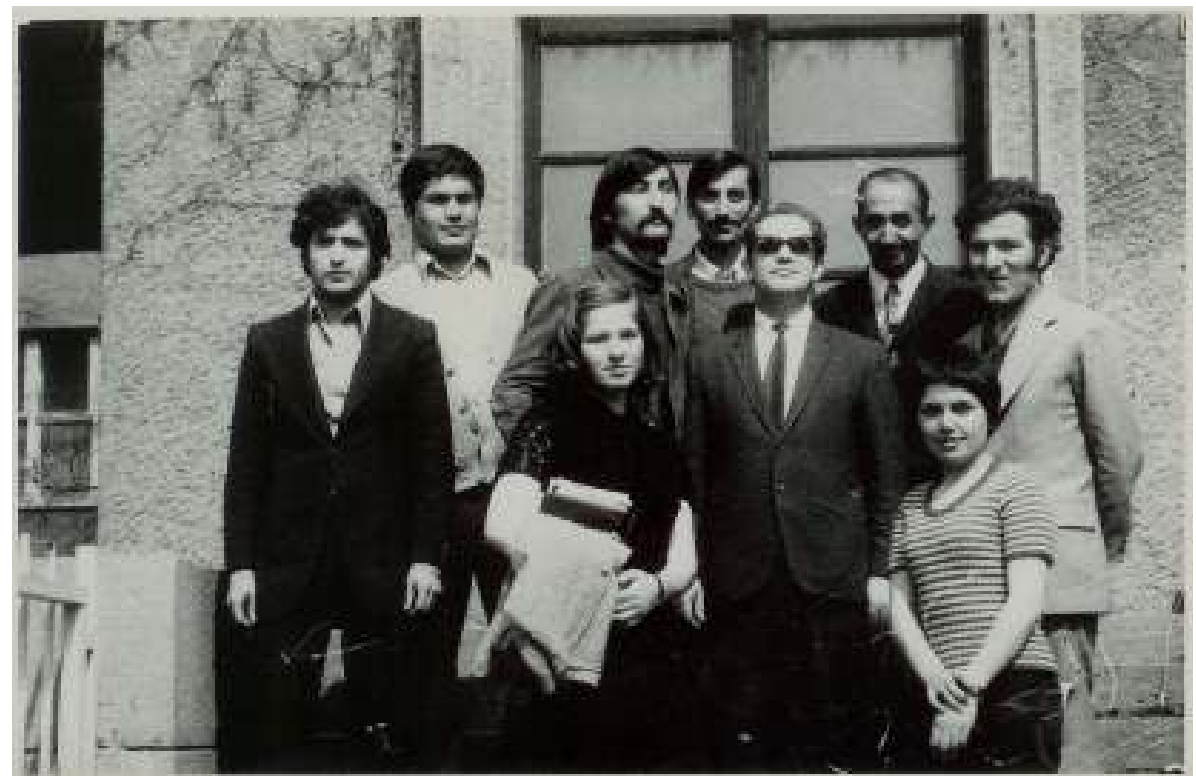

Prof. Dr. Alkan ve Ĕgitim Teknolojisi dersini alan ilk ögrenci grubu, 1972

Hocanın akıllarda kalan diğer bir özelliği ise vakur duruşu idi. İnsana saygıyı, mütevazılığı ve nezaketi bir araya getirdiği bu duruş biraz mesafeli olsa da insanda daima saygı uyandırırdı. Bir öğrencisi hocanın bu yönünü şöyle anlatıyor:

“...Onun mütevazıllğı bile vakur ve güzeldi. Kızması, gülmesi. Hiç kahkaha ile gülmedi mesela, ama hep gülümserdi."

Kızgınlığını asla sesinin tonuyla ifade etmezdi. Karşısındakini eleştirmeye, fikirlerini açılamaya yöneltir ve kimsenin sözünü kesmeden dinlerdi. Bununla birlikte daima açık sözlü idi. Düşündüğünü muhakkak en açık ve anlaşılır biçimde söylerdi. Ancak bu açık sözlülük herkese karşı eşit bir mesafede olduğundan kimse kırılmazdı. Bir öğrencisi hocanın bu yönünü “...açık sözlülükte adaletli ve kayırmacılıktan uzak” olarak nitelemektedir. 


\section{SONUÇ}

Prof. Dr. Alkan Ankara Üniversitesi Eğitim Bilimleri Fakültesi'nde ders vermeye başladığı 1972 yılından, aramızdan ayrıldığı 2007'ye kadar 35 yıl boyunca Eğitim Teknolojisi Alanı'nın hem bir bilim disiplini hem de bir uygulama alanı olarak Türkiye'de yaygınlaşması için çaba harcamıştır. Yoğun bilimsel çalışmalarının yanında, onun izinden giderek eğitim teknolojisi disiplin alanının gelişmesi için çalışmalarını sürdüren onlarca öğrenci yetiştirmiştir. Öğrencilerine derin bilimsel bilgi ve bakış açılarının yanı sıra, günümüz Türk Eğitim Teknolojisi camiasının özünü oluşturan bir bilimsel kültürü de aktarmıştır. Gerçekleştirdiği ilklerden bazıları şöyle stralanabilir:

- Eğitim teknolojisi disiplin alanını Türkiye'de kuran kişidir.

- Eğitim teknolojisi alanında ilk Türkçe kitabı o yazmıştır.

- Eğitim teknolojisi alanında Türkiye'de ilk doktora öğrencisini o yetiştirmiş̧ir.

- Türkiye'de eğitim bilimlerine ilişkin ilk kongreyi o düzenlemiştir.

- Türkiye'de uzaktan eğitim alanında yayın yapan ilk derginin editörlügünü o yürütmüştür...

Çalışmaları incelendiğinde Prof. Dr. Alkan'ın bilimsel yaşamının her yönüne, temelini yüksek lisans ve doktora öğreniminde attığı, eğitim felsefesinden-öğretmen yetiştirme ve mesleki teknik eğitime kadar uzanan geniş bir bakış açısı ve yoğun bilgi birikimini yansıttığı görülmektedir. Sayısı 120'ye yaklaşan bilimsel araştırma yelpazesi içerisinde, ağırlıklı olarak eğitim teknolojisi disiplini ele alınmakla birlikte; mesleki ve teknik eğitim, öğretmen yetiştirme ve eğitim felsefesi alanında da ürünler bulunmaktadır. Kitapları incelendiğinde eğitim teknolojisi disiplinini kuram ve uygulama boyutlarıyla; dünyada ve Türkiye'de toplumsal, ekonomik ve teknolojik değişimlerin yarattığı dönüşüm ve dönüşümün eğitim sisteminin öğretme-öğrenme süreçleri, ortam ve uzmanlık gibi bileşenleri üzerindeki etkilerini içeren çok yönlü bir bakış açısıyla ele aldığı görülmektedir. Eğitimin toplumsal, kültürel ve felsefi temellerinden, yeni çağın getirdiği dönüşüm gereksinimine uzanan bu bakış açısı eğitim teknolojisinin hem bir bilim disiplini olarak eğitim bilimleri içerisindeki yerine ve önemine işaret etmekte; hem de bir uygulama alanı olarak günümüz eğitim sorunlarına getirebileceği çözümler üzerinde durmaktadır.

Öğrencilerinin izlenim ve düşünceleri incelendiğinde Prof. Dr. Alkan için öne çıkan mesleki özelliklerin bilimsel gücü, çalışma disiplini, bilimsel duruşunda tutarlılığ 1 , çok yönlülüğü, yeniliğe açıklığ 1 ve özgünlüğü olduğu 
görülmektedir. Çok geniş bir çeşitlilikte okumuş, araştırmış, üretmiş ve ürünlerini sürekli geliştirerek güncel tutmuştur. Her zaman yeniliklerin takipçisi olmuştur. Bu yenilenme salt bilimsel bakış açısında kalmamış, akademik ilgilerinden derslerinde kullandığı materyal ve teknolojilere kadar yayılmıştır. Tepegöz teknolojisini ülkemizde etkin kullanan ilk hocalardan olmuş, tüm ders materyallerini tepegöz saydamlarına dönüştürmüştür. Hazırladığı saydamlar öğrencileri tarafından bugün bile anımsanmaktadır.

Bir hoca olarak Prof. Dr. Alkan denince zor beğenmesi, demokratik tutumları ve tatl1-sert tarzı anımsanmaktadır. Cevat hoca hep zor beğenmiş, öğrencilerini gelişmeye yöneltmiştir. Sınıfında demokrasiyi yaşatmış, öğrencilerini kendi görüşlerini, farklı bakış açılarını ifade etmeleri için güdülemiştir. Yetiştirdiği insanlara her zaman güven ve cesaret vermiştir. Çevresindeki sorunlara daima duyarlı olmuş, asistanlarının, öğrencilerinin yaşam sorunlarıyla da yakından ilgilenmiştir. Bu doğrultuda birlikte çalıştığ insanlara bilimsel bilgi birikimi ötesinde akademik bir kültürü de miras bırakmıştır. Mesleğe saygıyı yaşamının merkezine koymuş, meslektaşlarından-öğrencilerine birlikte çalıştığı herkese bu saygıyı, nezaketi ve inceliği yansıtmıştır. 30 yılı aşkın meslek yaşamında sadece bir kez dersine geç kaldığı anımsanmaktadır.

Tüm bu yönleri ile "alanın ulu çınarı, Türkiye'de eğitim teknolojisinin babası" olarak adlandırdığımız değerli hocamızı A. Ü. Eğitim Bilimleri Fakültesi'nde çalışmaya başlamasının 40. yılında saygı ve rahmetle aniyoruz.

Teşekkür: Veri toplama sürecinde Prof. Dr. Alkan'ın ögrencileri ve çalışma arkadaşları olarak katkı ve desteklerini esirgemeyen tüm değerli katılımcılara ve özellikle bulguların yapılandırılmast sürecindeki katkilarından ötürü Prof. Dr. Hafize KESER'e teşekkür ediyoruz. 


\section{KAYNAKLAR}

Alkan, C. (1974). Eğitim teknolojisi. Ankara Üniversitesi Eğitim Bilimleri Fakültesi Dergisi, 7(1), 339-345.

Alkan, C. (1977). Eğitim teknolojisi kuramlar ve yöntemler. Ankara: Yargıçoğlu Matbaasi.

Alkan, C. (1984). Eğitim teknolojisi: kavram kapsam süreç ortam işgören uygulama (2. baskl). Ankara: Yargıçoğlu Matbaası.

Alkan, C. (1987). Açıköğretim: uzaktan ĕgitim sistemlerinin karşılaştırmalı olarak incelenmesi. Ankara: Ankara Üniversitesi Eğitim Bilimleri Fakültesi Yayınları No: 157.

Alkan, C., Deryakulu, D., ve Şimşek, N. (1995). Eğitim teknolojisine giriş: disiplin süreç ürün. Ankara: Neva Kitabevi.

Alkan, C., ve Kurt, M. (1998). Özel ögretim yöntemleri: disiplinlerin ögretim teknolojisi. Ankara: Anı Yayıncılık.

Alkan, C., ve Teker, N. (1992). Programlı öğretim: değişik teknolojiler ve Türkiye'deki uygulama. Ankara: Ankara Üniversitesi Eğitim Bilimleri Fakültesi Yayınları No: 169.

Ankara Üniversitesi Eğitim Bilimleri Fakültesi. (2011). Prof. Dr. Cevat Alkan'a ait fakülte personel dosyass. A. Ü. Ĕgitim Bilimleri Fakültesi Personel İşleri Şefliği $(\mathrm{Bu}$ inceleme Eğitim Bilimleri Fakültesi Dekanlığı'nın izni ile gerçekleştirilmiştir).

Borg, W. R. (1963). Educational research: an introduction. London: Longman.

Cohen, L., Manion, L., \& Morrison, K. (2007). Reseacrh methods in education (6th Edition). London, New York: Routledge .

Frankel, J. R., \& Wallen, N. E. (2009). How to design and evaluate research in education (7th edition). Boston: McGraw-Hill.

Milli Eğitim Bakanlı̆̆ı (2012). Müsteşarlarımız. http://mub.meb.gov.tr/mustesarlarimiz.php adresinden 6 Nisan 2012 tarihinde alınmıştır.

Reiser, A. R., \& Dempsey, J. V. (Eds.) ( 2002). Trends and issues in instructional design and technology. Upper Saddle River, NJ: Merrill/Prentice Hall.

Yıldırım, A. ve Şimşek, H. (2006). Sosyal bilimlerde nitel araştırma yöntemleri (6. baskı). Ankara: Seçkin Yayıncılık. 


\section{EK 1: Prof. Dr. Cevat Alkan’ın Başlıca Eserleri}

\section{Kitapları}

- Özel Öğretim Yöntemleri: Disiplinlerin Öğretim Teknolojisi (M. Kurt ile birlikte), 1998. Ankara: Anı Yayıncılık.

- Eğitim Teknolojisi (5. Baskı), 1997. Ankara: Anı Yayıncılık.

- Eğitim Teknolojisine Giriş: Disiplin Süreç Ürün (D. Deryakulu ve N. Şimşek ile birlikte), 1995. Ankara: Neva Kitabevi.

- Öğretmenlik Uygulamaları: Öğretim Teknolojisi (F. Hacığlu ile birlikte), 1995. Ankara: Önder Matbaac1lık.

- Eğitim Teknolojisi (4. Baskı), 1995. Ankara: Atilla Kitabevi.

- Programlı Öğretim: Değişik Teknolojiler ve Türkiye'deki Uygulama (N. Teker ile birlikte), 1992. Ankara: A.Ü. Eğitim Fakültesi Yayınları No: 169.

- Öğretmen Eğitimi, 1990. Ankara: T.C. M.E.B. Çıraklık ve MeslekiTeknik Eğitimi Konseyi.

- Eğitim Bilimleri: I. Ulusal Kongresi Değerlendirme Raporları, 1990. Ankara: A.Ü. Eğitim Bilimleri Fakültesi Yayın No:165.

- Eğitim Teknolojisinin Temel Bir Öğesi Olarak Eğitim Ortamlarının Düzenlenmesi, 1992. Ankara: A.Ü. Eğitim Fakültesi Yayınları No: 168.

- Özel Öğretim İlke ve Yöntemleri: Özel Öğretim Teknolojileri, 1991. Ankara: A.Ü. Eğitim Bilimleri Fakültesi Yayınları No: 167.

- Mesleki Teknik Eğitimin Esasları (H. Doğan ve İ. Sezgin ile birlikte), 1988. Ankara: G.Ü. Teknik Eğitim Fakültesi Matbaası.

- Açıköğretim: Uzaktan Eğitim Sistemlerinin Karşılaştırılmalı Olarak İncelenmesi, 1987. Ankara: A.Ü. Eğitim Bilimleri Fakültesi Yayın No: 157.

- Eğitim Teknolojisi, 1987. Eskişehir: Anadolu Üniversitesi Açıköğretim Fakültesi Yayınları.

- Öğretmeyi Öğretmek (H. Taymaz ile birlikte), 1987. Ankara: Eğitim Seti No:1, T.C. Devlet Bakanlı̆̆1 Yayın No:26.

- Öğretmenlik Uygulamaları El Kitabı, 1987. Ankara: Yargıçoğlu Matbaasi.

- Eğitim Teknolojisi: Kavram Kapsam Süreç Ortam İşgören Uygulama (2. Bask1), 1984. Ankara: Yargıçoğlu Matbaası.

- Eğitim Felsefesi, 1983. Bursa: Uludağ Üniversitesi Eğitim Fakültesi Yayını.

- Mesleki Teknik Eğitim Prensipleri (H. Doğan ve İ. Sezgin ile birlikte), 1980. Ankara: A. Ü. Eğitim Fakültesi Yayınları No: 90. 
- Eğitim Ortamları, 1979. Ankara: A.Ü. Eğitim Fakültesi Yayınları No: 55.

- Yaygın Mesleki ve Teknik Öğretimde Eğitim Teknolojisi, 1978. Ankara: Milli Eğitim Bakanlığı Mesleki ve Teknik Öğretim Yüksek Danışma Kurulu.

- Eğitim Teknolojisi : Kuramlar Yöntemler, 1977. Ankara: Yargıçoğlu Matbaas1.

- Mesleki ve Teknik Öğretimde Reform, 1971. Ankara: Baylan Basım ve Ciltevi.

- Ağaçişleri Endüstrisinde Yenilikler, 1964. Ankara: Ağaçişleri Olgunlaşma Enstitüsü.

- Ağaçişleri Okul Atölyelerinin Yönetimi ve Organizasyonu, 1964. Ankara: Ağaçişleri Olgunlaşma Enstitüsü.

\section{Editörlüğünü Üstlendiği Kitapları}

- Eğitim Teknolojisi: Bildiriler I, 1990. Eğitim Bilimleri: I. Ulusal Kongresi 24-28 Eylül 1990. Ankara: Milli Eğitim Basımevi.

- Biyoloji Öğretimi, 1991. Anadolu Üniversitesi Açık Öğretim Fakültesi Biyoloji Lisans Tamamlama Programı. Eskişehir: Anadolu Üniversitesi Açık Öğretim Fakültesi Yayınları No: 182.

- Coğrafya Öğretimi, 1991. Anadolu Üniversitesi Açık Öğretim Fakültesi Coğrafya Lisans Tamamlama Programı. Eskişehir: Anadolu Üniversitesi Açık Öğretim Fakültesi Yayınları No: 175.

- Kimya Öğretimi, 1991. Anadolu Üniversitesi Açı Öğretim Fakültesi Kimya Lisans Tamamlama Programı. Eskişehir: Anadolu Üniversitesi Açık Öğretim Fakültesi Yayınları No: 189.

\section{Çeviri Kitapları}

- Endüstriyel ve Organizasyonel Psikoloji (Abraham K. Korman Öğretmen Kitapları: 141), 1978. Ankara: Milli Eğitim Basımevi.

- Ağaç Tornacılığı, 1961. Ankara: Teknik Yüksek Öğretmen Okulu Matbaasi.

- Okul Atelyelerinin Geliştirilmesi (Araştırma ve Planlama), 1971. Ankara: MEB EPD yayınları No: 68.

- Eğitim Planlamasında Danışmanın Rolü, 1974. Ankara: Talim Terbiye Dairesi Yayınları. 


\section{Bazı Makaleleri}

- Bilim Ötesi: Beşeri Bilimlerin İletişim Kuramlarına Katkısı, 1991. A. Ü. Eğitim Fakültesi Dergisi, 24(2), 283-313.

- Öğrenme-Öğretme Durumunun Temel Bir Öğesi Olarak Öğretim Araçları Üzerine Bir Öğretim Ünitesi, 1990. A. Ü. Eğitim Fakültesi Dergisi, 23(2), 507-521.

- Eğitim Bilimlerinde Araştırma, 1989. A. Ü. Eğitim Fakültesi Dergisi, 22(1), 23-27.

- Modüler Programlama ve Türkiye'deki Uygulaması, 1989. A. Ü. Eğitim Fakültesi Dergisi, 22(1), 13-22.

- Bilgisayar Destekli Öğrenme Modülleri, 1988. A. Ü. Eğitim Fakültesi Dergisi, 21(1), 255-263.

- Bir Eğitim Ortamı Olarak Video, 1988. A. Ü. Eğitim Fakültesi Dergisi, 21(1), 265-270.

- Eğitim Teknolojileri Araştırmaları "Radyo Ve Televizyonun Diğer Eğitim Ortamlarıyla Birlikte Kullanılması", 1986. A. Ü. Eğitim Fakültesi Dergisi, 19(1), 9-26.

- Eğitimde Ergonomi (Çeviri), 1983. A. Ü. Eğitim Fakültesi Dergisi, 16 (1), 197-206.

- Üniversite Yönetiminde İletişim, 1983. A. Ü. Eğitim Fakültesi Dergisi, 16 (2), 11-26.

- Uzaktan Eğitimde Öğretim Yöntemleri (Çeviri), 1982. Çağdaş Eğitim 7 (63-64), 3-19, 15-23.

- Eğitim Teknolojisi ve Öğretmen Eğitimi, 1982. A. Ü. Eğitim Fakültesi Dergisi, 15 (1), 377-394.

- Eğitim Felsefesi ve Teknik eğitim Arası İlişki, 1982. Eğitim ve Bilim 7(39), 4-6.

- Öğretmen Eğitiminde Televizyon, 1982. Eğitim ve Bilim 7 (40), 9-18.

- Açık Üniversite, 1981. A. Ü. Eğitim Fakültesi Dergisi, 14 (1-2), 33-40.

- Eğitim-Din Arası İlişki, 1980. Eğitim ve Bilim 5 (26), 32-40.

- Atatürk Düşüncesi ve Eğitim, 1978. A. Ü. Eğitim Fakültesi Dergisi, 10 (1-2), 293-304.

- Öğretmen Eğitimi, 1977. A. Ü. Eğitim Fakültesi Dergisi, 9 (1-4), 95-115.

- Eğitim Teknolojisi, 1975. A. Ü. Eğitim Fakültesi Dergisi, 7 (1-4), 339344.

- Çağdaş Türk Toplumunun Eğitim Sorunları ve Kooperatif Eğitim Programları, 1972. Mesleki ve Teknik Öğretim, 20 (230), 6-10.

- Eğitimde Yenilikler-Verbo-Tonnal Metot, 1972. Mesleki ve Teknik Öğretim, 20 (235), 23-25. 